\title{
Halophila baillonis Ascherson: first population dynamics data for the Southern Hemisphere
}

\author{
KARINE M. MAGALHÃES ${ }^{1}$, JOÃO C.G. BORGES ${ }^{2}$ and MARIA E. PITANGA ${ }^{2}$ \\ ${ }^{1}$ Departamento de Biologia, Universidade Federal Rural de Pernambuco/UFRPE, \\ Rua Dom Manoel de Medeiros, s/n, Dois Irmãos, 52171-900 Recife, PE, Brasil \\ ${ }^{2}$ Fundação Mamíferos Aquáticos, Av. 17 de Agosto, 2001, $1^{\circ}$ andar, Casa Forte, 52061-540 Recife, PE, Brasil \\ Manuscript received on May 8, 2014; accepted for publication on October 25, 2014
}

\begin{abstract}
The present paper presents the first population data for the Southern Hemisphere of the rare seagrass Halophila baillonis. The population studied is located in a calm, reef-protected area at depths $\leq 5 \mathrm{~m}$, covering $12,000 \mathrm{~m} 2$ (400 m long by $30 \mathrm{~m}$ wide, oriented parallel to the coastline). The population generally demonstrated low shoot density and biomass during the rainy season, with significant differences between seasons, being found only for aboveground biomass. Despite the identification of this new population, the species continues to be considered rare along the Brazilian coast.
\end{abstract}

Key words: vulnerable species, new population, seagrass, shoot density.

\section{INTRODUCTION}

The seagrass Halophila baillonis Ascherson is considered a vulnerable species according to the International Union for Conservation of Nature (IUCN) (Short et al. 2010) as it is rare in nature and, when encountered, occurs only in fragmented populations. Its populations appear to be declining due to anthropogenic impacts (Short et al. 2010). The distribution range of $H$. baillonis is restricted to the Tropical Atlantic region (Short et al. 2007), with recorded occurrences only in approximately eight localities in the Caribbean (Short et al. 2010) and one along the Pacific coast of Costa Rica (SamperVillarreal et al. 2014), with historical records in Brazil (den Hartog 1970, 1972, Oliveira-Filho et al. 1983) and Costa Rica (Pacific coast) (Cortes

Correspondence to: Karine Matos Magalhães

E-mail: karinematosmagalhaes@gmail.com
2001). Ecological information about this species is limited to its distribution in the western Caribbean area (Short et al. 2006) and its association with other seagrass meadows (Cortes 2001), as well as a characterization of seagrass meadows and the associated benthic macrofauna on the southern Pacific coast of Costa Rica (Samper-Villarreal et al. 2014). There have been no published observations of seasonal variations of $H$. baillonis populations, as most of them are scarce and fragmented.

The only two previous records of this species in Brazil were provided by Setchell (1934) based on material collected in 1888 at the Itamaracá Island in the state of Pernambuco (den Hartog 1970, 1972) and by Oliveira-Filho et al. (1983), citing a single specimen (without flowers or fruits) collected near Recife, also in the state of Pernambuco State. Because of the time lapse with no new records, 
H. baillonis has been considered rare (Short et al. 2010), poorly studied (Barros et al. 2013), or even possibly extinct (Marques and Creed 2008).

This paper provides the first population dynamic study of shoot density and biomass for Halophila baillonis in the Southern Hemisphere, and also presents the first population known for the Brazilian coast - more than three decades after the last report of its occurrence.

\section{MATERIALS AND METHODS}

Apopulation of Halophila baillonis was encountered in the Mamanguape River Bar Environmental Protection Area (created by Decree No. 924, September 10, 1993) (647'41" S; 3503'15" W), in the state of Paraíba, northeastern Brazil. This conservation area has ecological importance as one of the main habitats and feeding grounds of the Antillean manatee (Trichechus manatus manatus) in Brazil. The regional climate is defined by two distinct periods: a dry season (September to February) and a rainy season (March to August). The mean precipitation and temperature for the area is $1763 \mathrm{~mm} /$ year and $26^{\circ} \mathrm{C}$, respectively (Andrade and Lins 2005).

Manually collected specimens were identified based on Oliveira-Filho et al. (1983) and Kuo and den Hartog (2001). The species is being referred to here as $H$. baillonis, and not $H$. baillonii, based on Kuo and Wilson (2008).

The meadow area was measured and a $5 \mathrm{~cm}$ diameter core sample (15 cm depth) was taken to characterize sediment composition. Plant samples were obtained during the rainy and dry seasons (June/2013 and January/2014, respectively) in $9.8 \mathrm{~cm}$ diameter core samples in the sediment to a depth of $10 \mathrm{~cm}(\mathrm{n}=5)$. The shoots in each core sample were counted for shoot density estimates (shoots $\mathrm{m}^{-2}$ ) and the above- and belowground biomass were calculated after the samples were dried to a constant weight at $\left.60{ }^{\circ} \mathrm{C}(\mathrm{g} \mathrm{dw} \mathrm{m})^{-2}\right)$. To test whether shoot density and above- and belowground biomass varied between different collecting periods, we used the separate variance t-test (also known as the Welch test), as it does not assume equal variance between groups (Quinn and Keough 2002).

\section{RESULTS}

The Halophila baillonis population was located in June/2013 in a mixed meadow (together with Halodule wrightii and Halophila decipiens) in a calm, reef-protected area at depths $\leq 5 \mathrm{~m}$. The meadow covered $12,000 \mathrm{~m}^{2}$ (400 m long by $30 \mathrm{~m}$ wide, oriented parallel to the coastline). $H$. baillonis was found in the shallow area of the meadow ( 2 to 3 $\mathrm{m}$ depth), sometimes mixed with the other species; $H$. wrightii and $H$. decipiens were dominant in the deeper areas (3-4 m). The sediment consisted of a surface layer of rounded pebbles and bioclastic matter, approximately $10 \mathrm{~cm}$ deep over fine sand.

The plants have fragile rhizomes (0.6-1.5 $\mathrm{mm}$ in diameter), with 1 root at each node, and internodes 9-23 mm long; stems 10-24 mm long, erect, bearing (in the middle portion) 2 scales that are obovate, keeled, glabrous, 3-5 mm long; 4 leaves are arranged in a pseudo-whorl at the tip of the stem. Blades oblong, ovate, elliptic to lanceolate, 7-12 mm long, 3-4 mm wide, with 3-5 unbranched cross-veins on each side of the pronounced midrib, margin finely serrulate (Fig. 1). Flowers and fruits were not seen. Shoot density varied from 133 to 2,520 shoots. $\mathrm{m}^{-2}$; aboveground biomass varied between 0.13 and 4.38 g.dw.m ${ }^{-2}$, and below-ground biomass varied between 0.53 and 12.47 g.dw.m ${ }^{-2}$, with significant differences between the dry and rainy seasons only for aboveground biomass $(\mathrm{t}=$ 2.3419; $p=0.02748)$ (Table I).

\section{DISCUSSION}

This record in Brazil expands the original distribution area in the state of Pernambuco (07'32'00" -

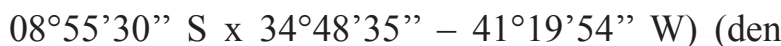
Hartog 1970, 1972, Oliveira-Filho et al. 1983) by 


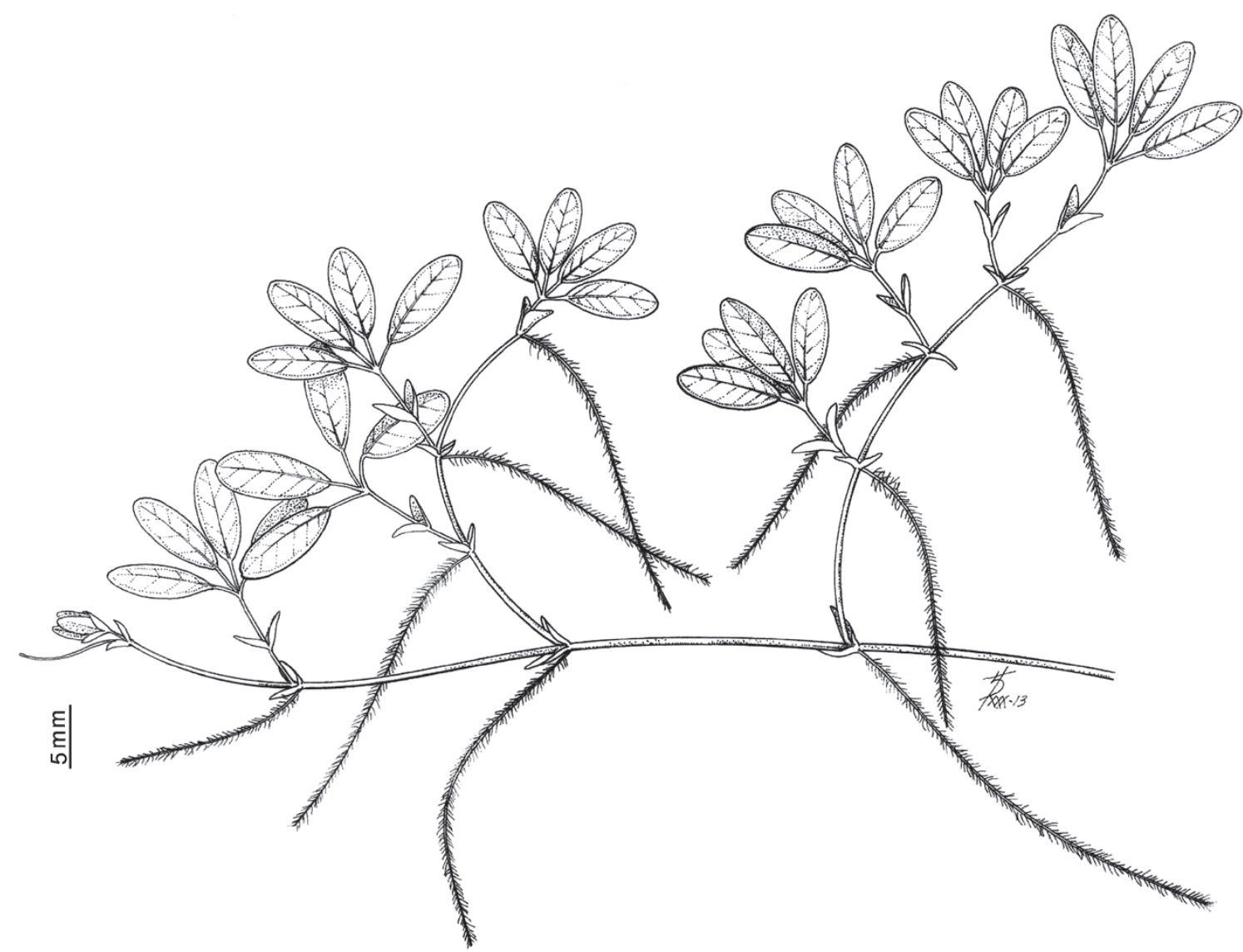

Figure 1 - Halophila baillonis collected in the Mamanguape River Bar Environmental Protected Area in Paraíba State, northeastern Brazil (June/2013).

TABLE I

Biotic parameters of Halophila baillonis (Shoot density, above- and belowground biomass) at the Mamanguape River Bar Environmental Protection Area in Paraíba State, northeastern Brazil, between June/2013 (the rainy season) and January/2014 (the dry season). RS = rainy season; DS = dry season.

\begin{tabular}{|c|c|c|c|}
\hline Variable & Average $( \pm \mathrm{SE})$ & Range & Differences \\
\hline Shoot density & $\begin{array}{c}920 \pm 312 \text { shoot. } \mathrm{m}^{-2}(\mathrm{RS}) \text { and } \\
1698 \pm 352 \text { shoot. } \mathrm{m}^{-2}(\mathrm{DS})\end{array}$ & $\begin{array}{c}133 \text { shoot. } \mathrm{m}^{-2}(\mathrm{RS}) \text { and } \\
2520 \text { shoot. } \mathrm{m}^{-2}(\mathrm{DS})\end{array}$ & $\mathrm{t}=1.6912, \mathrm{p}=0.0649$ \\
\hline Aboveground biomass & $\begin{array}{c}1.27 \pm 0.58 \text { g.dw.m }{ }^{-2} \text { (RS) and } \\
2.23 \pm 0.69 \text { g.dw.m }{ }^{-2} \text { (DS) }\end{array}$ & $\begin{array}{l}0.13 \text { g.dw.m }{ }^{-2}(\mathrm{RS}) \text { and } 4.38 \\
\text { g.dw.m } \mathrm{m}^{-2}(\mathrm{DS})\end{array}$ & $\mathrm{t}=2.3419, \mathrm{p}=0.02748$ \\
\hline Belowground biomass & $\begin{array}{c}2.75 \pm 1.26 \text { g.dw.m }{ }^{-2}(\mathrm{RS}) \text { and } \\
4.54 \pm 2.08 \text { g.dw.m } \\
\text {-2 (DS) }\end{array}$ & $\begin{array}{c}0.53 \text { g.dw.m } \text { m }^{-2}(\mathrm{RS}) \text { and } 12.47 \\
\text { g.dw.m }\end{array}$ & $\mathrm{t}=2.0244, \mathrm{p}=0.0532$ \\
\hline
\end{tabular}

$140 \mathrm{~km}$ to the north of the state of Paraíba $\left(6^{\circ} 02^{\prime}\right.$ $12^{\prime}-8^{\circ} 19^{\prime} 18^{\prime} \mathrm{S} \times 34^{\circ} 45^{\prime} 45^{\prime} \mathrm{W}$ ) and indicates that H. baillonis is not extinct along the Brazilian coast. This is, in fact, the first population recorded for the Brazilian coast, as the 1983 record was based on just a single specimen (Oliveira et al. 1983), and there is no detailed information available for the plants collected in 1888 (den Hartog 1972).

The Brazilian meadow is oriented parallel to the coastline (similar to those reported for Belize) (Short et al. 2006), but $H$. baillonis was found in the shallow region of the meadow, different from 
the situation reported for Costa Rica - where $H$. baillonis was found in the deepest meadow zone dominated by Ruppia maritima (Cortes 2001). This distribution may be related to its capacity to succeed in turbid waters (as suggested by Short et al. 2006), as its growth form (also observed in the Brazilian population) has horizontally oriented leaves elevated above the bottom on erect stems.

Although the meadow area recorded in the present study is larger than the (only other) meadow reported in Costa Rica (Samper-Villarreal et al. 2014), its density and biomass were lower than those reported for Costa Rica - which may reflect its natural distribution limits. Another possible explanation for the larger populations observed in Costa Rica could be related to species competition, as the Costa Rica meadow is monospecific (Samper-Villarreal et al. 2014). Variations within monospecific populations have also been observed in the Caribbean, and were found to be related to sediment composition or water depth (Short et al. 2010). This species can be found at depths up to $15 \mathrm{~m}$, but is most commonly found between depths of 1 and $3 \mathrm{~m}$ (Short et al. 2006) - as reported for both the Brazilian and the Costa Rica population (Samper-Villarreal et al. 2014).

Locating and mapping new populations are fundamental for monitoring seagrass, as its cover appears to be declining worldwide (Orth et al. 2006, Waycott et al. 2009). Anthropogenic impacts and climatic changes are among the main factors responsible for these losses, and understanding environmental influences on seagrasses may help predict and prevent further losses of seagrasses, their ecological services, and the biodiversity associated with these habitats (Barros et al. 2013). Although the area where the present study was undertaken is protected by law, there are records of historical anthropogenic impacts there - including human population expansion (Native American villages), shrimp farming, and sugarcane cultivation (Silvestre et al. 2011). During the collection period, local fishing and the presence of tourists and motorized recreational crafts (such as jet skis) were observed in the area. The administration of the Mamanguape River Bar Environmental Protection Area is currently reviewing its management procedures to determine the most effective ways to deal with activities that could negatively impact the local biota - including two threatened species: $H$. baillonis and the Antillean manatee. As has been observed in other regions (Short et al. 2006, 2010), this seagrass species apparently is part of the diet of these animals.

In spite of the identification of this new population, $H$. baillonis continues to be considered rare. Efforts to map seagrass distributions along 950 $\mathrm{km}$ of shoreline in northeastern Brazil between the states of Rio Grande do Norte and Alagoas reported this site as the single record of occurrence in over 60 areas surveyed (Alves et al. In press). Surveys further North are being carried out as well as longterm monitoring of this new population of $H$. baillonis to characterize its reproductive cycle, the variations in vegetation cover, and the associated biodiversity to help manage it and predict possible changes to its population structure - associated with efforts to increase awareness about the importance of this ecosystem.

\section{ACKNOWLEDGMENTS}

This paper is the result of efforts of the "Viva o Peixe-Boi Marinho" manatee conservation project, sponsored by Petrobras through the Petrobras Socioenvironmental Program. We would like to thank biologist Silmar Luiz Silva for his assistance with the preparation of herbarium specimens, as well as Dr. Evamaria Koch for suggestions to this manuscript and her review of an earlier version.

The first author would like to dedicate this paper to Dr. Evamaria Koch in recognition of her enthusiasm, dedication, and remarkable contributions to seagrass studies throughout the world, especially along the northeastern coast of Brazil. 


\section{RESUMO}

O presente artigo apresenta os primeiros dados populacionais sobre a rara angiosperma marinha Halophila baillonis. A população está localizada em uma área protegida por recifes com profundidade média de $5 \mathrm{~m}$, cobrindo uma área de $12000 \mathrm{~m}^{2}$ (400 m de comprimento por $30 \mathrm{~m}$ de largura, paralela a linha de praia). A população apresentou, em geral, menores densidades de hastes e valores de biomassa durante a estação chuvosa com diferenças significativas entre estações do ano registradas, apenas, para biomassa aérea. Apesar deste novo registro a espécie continua a ser considerada rara na costa brasileira.

Palavras-chave: espécie vulnerável, nova população, angiosperma marinha, densidade de hastes.

\section{REFERENCES}

Alves Mdo, Pitanga ME, AraúJo ME, Cunha SR AND MAGALHÃES KM. IN PRESS. Seagrass distribution in relation to the occurrence of the Antillean manatee in northeastern Brazil.

ANDRADE GO AND LINS RC. 2005. Os climas do Nordeste. In: Vasconcelos Sobrinho J (Ed), As regiões naturais do Nordeste, o meio e a civilização. Recife: CONDEPE, p. $95-138$.

BARRos KVS, RochA-BARREIRA CA AND MAGALHÃES KM. 2013. Ecology of Brazilian seagrasses: Is our current knowledge sufficient to make sound decisions about mitigating the effects of climate change? Iheringia Sér Bot 68(1): 163-178.

CORTES J. 2001. Requiem for an eastern Pacific seagrass bed. Rev Bio Trop 49(Suppl 2): 273-278.

Den Hartog C. 1970. The sea-grasses of the world. Tweed Reeks 59(1): 5-275.

Den Hartog C. 1972. The sea-grasses of Brazil. Acta Bot Neerl 21(5): 512-516.
Kuo J And Den Hartog C. 2001. Seagrass taxonomy and identification key. In: Short FT and Coles RG (Eds), Global Seagrass Research Methods. Amsterdam: Elsevier Science, p. 31-58.

KUO J AND WILSON PG. 2008. Nomenclature of the Seagrass Halophila baillonis Ascherson. Aq Bot 88: 178-180.

MARQueS LV AND CREED JC. 2008. Biologia e ecologia das fanerógamas marinhas do Brasil. Oecol Bras 12: 315-331.

OliveIRA-FILHo EC, PIRANI JR AND GIULIETTI AM. 1983. The Brazilian Seagrass. Aq Bot 16: 251-267.

ORTH RJ ET AL. 2006. A global crisis for seagrass ecosystems. Biosci J 56: 987-996.

QuinN GP AND KeOUgh MJ. 2002. Experimental Design and Data Analysis for Biologists. London: Cambridge, $556 \mathrm{p}$.

SAMPER-VILlarREAl J, BOURG A, SibAJA-CORDERO JA AND CORTÉs J. 2014. Presence of a Halophila baillonii Asch. (Hydrocharitaceae) seagrass meadow and associated macrofauna on the Pacific coast of Costa Rica. Pac Sci 68 (3): 435-344.

SETCHELL WA. 1934. South American seagrasses. Revista Sudamer Bot 1: 107-110.

SHORT FT, CARRUTHERS T, DENNISON W AND WAYCOTT M. 2007. Global seagrass distribution and diversity: a bioregional model. J Exp Mar Biol Ecol 350: 3-20.

SHORT FT, CARruthers TJR, VAN TUSSENBROEK B AND ZIEMAN J. 2010. Halophila baillonii. In: IUCN International Union for Conservation of Nature, 2012. IUCN Red List of Threatened Species. Version 2012.2. $<$ www.iucnredlist.org $>$. Downloaded on 25 June 2013.

Short FT, FERnANDEZ E, VERnON A AND GAECKLE JL. 2006. Occurrence of Halophila baillonii meadows in Belize, Central America. Aq Bot 85: 249-251.

Silvestre LC, FARIAS DLS, LOURENÇO JDS, BARRos SCA AND BRAGA NMP. 2011. Diagnóstico dos impactos ambientais advindo de atividades antrópicas na APA da Barra do Rio Mamanguape. Enciclopédia Biosfera, Centro Científico Conhecer - Goiânia 7(12): 1-11.

WAyCOTT M ET AL. 2009. Accelerating loss of seagrasses across the globe threatens coastal ecosystems. Proc Natl Acad Sci U S A 106(30): 12377-12381. 
